\title{
Strategy for Rice Disease Management in Bangladesh
}

\author{
M T Khatun ${ }^{1 *}$, B Nessa ${ }^{1 *}$, M U Salam² and M S Kabir ${ }^{3}$
}

\begin{abstract}
Disease is one of the most limiting biotic factors that affects rice production worldwide. In Bangladesh, there are 10 rice diseases considered as major, which cause economic loss in farmers' fields. Therefore, the aim of this article is to explore all the feasible avenues of technology deployment on rice disease management to restrict the disease infection at minimum level and thus minimize economic loss. The article is generated using data and/or infromation from published and unpublished works and incorporating authors' experience. It is evident that periodically (odd year) a disease outbreak or epidemic occurred in Bangladesh such as blast. Under epidemic situation, research findings estimated a yield loss of up to $98 \%$ at the highest disease severity level of infection of blast. On the other hand, field survey indicated the highest of $65.4 \%$ yield loss from severly infected field with the disease. To overcome the epidemics in odd years and to keep the loss under economic threshold level, it is necessary to undertake preventive measures such as planting of resistant or tolerant varieties, use of disease-free seeds from healthy plants, use of balanced fertilizer where applicable, and following feasible crop rotations. Currently, it is urgent need for developing strong and precise weather-based disease-risk forecasting system at least one week's lead time based on real-time weather data. Subsequent quick management options such as disease-specific fungicidal treatment should be communicated to all stakeholders using fast-delivery media such as TV channels and SMS could be efficient and effective ways to address the disease outbreak under epidemic situation. To address annualized yield loss, it is suggested to execute interventions like effective training to the root level (both for farmers and extension personnel) and conducting demonstration in farmers fields, regular field monitoring, digitalization in disease management sector, revive indigenous technologies as appropriate, and improving rice production system. To continously improve rice disease management sector, this paper has proposed an innovative action for three decades through to 2050 under the banner 'Location, Variety and Disease Specific Smart Management' on research, development and extension.
\end{abstract}

Key words: Rice disease, effective training, monitoring, digitalization, epidemiology

\section{INTRODUCTION}

Global rice production is expected to face more challenges in the coming years, and Bangladesh is predicted to be exposed to more of those tricky situations. Those challenges include different bio-aggressors especially diseases of rice crop. Rice is anticipated to continue to be the major human staple food crop well into the $21^{\text {st }}$ century (Zeigler et al., 1994). Therefore, we must think of the rice security for the generations of the next decades. And, to meet the demand, we must rethink about the efforts to reduce the risk of the losses caused by different diseases for sustainable rice production. It has been stated that the development and release of high input loving, high yielding cultivars are altering the micro-ecobalance, resulting in severe disease problems (Shahjahan, 1993). Quantified annual yield losses based on surveys due to a combination of rice diseases ranged from 1 to $10 \%$ in Asia (Rice diseases workshop, 2014). Unfortunately, there is no precise and updated yield loss data accounting for rice diseases for the whole nation. Our projected clean rice production for 2050 has been set as 40.40 million tons (Kabir et al., 2015). To achieve this estimated production and minimize the losses caused by diseases, it would be necessary to fully utilize existing resources, as indicated in Kabir et al. (2020). The farmers of Bangladesh

\footnotetext{
1Senior Scientific Officer, Plant Pathology Division, Bangladesh Rice Research Institute (BRRI), Gazipur-1701, Bangladesh; ${ }^{2}$ Freelance International Consultant (Agricultural Systems), Bangladesh; ${ }^{3}$ Director General, BRRI, Gazipur-1701, Bangladesh. *Corresponding author's E-mail: tuhinabrri17@gmail.com (M T Khatun); runu.brri@yahoo.com (B Nessa)
} 
are the catalyst to make the country selfsufficient in food production. Therefore, it is pertinent to transmit all of our knowledge, information, and technologies to the farmers to get maximum return from rice production.

With the above background, this article undertook three specific objectives in relation to rice diseases in Bangladesh: (i) presentation of their changing status, (ii) highlighting the scenarios of yield loss associated with the diseases, and (iii) development and mapping the action plan for three decades on reducing yield loss from the diseases.

\section{METHODOLOGY}

The study contains the information mostly conceptualized by the authors. Most data and some ideas were derived from secondary sources, which have been appropriately cited. A number of works (Shahjahan, 1993; Thurston, 1994; Shen and Lin, 1994; Teng, 1994; Islam and Catling, 2012; Arya, 2018) were used for reviewing purposes. The published and unpublished data on yield loss for four diseases - sheath rot, sheath blight, false smut, and blast presented in graphs in this paper were collected either from farmers' fields or research fields are mostly from authors own research findings data. A simple diagram has been proposed on networking between farmers' field problems and researchers. The idea for this was burrowed from Rhoades and Booth (1982). The baseline data for yield loss were estimated by group discussion. The set of disease data were derived from farmers' demonstration those were conducted by plant pathologists of the Plant Pathology Division in Bangladesh Rice Research Institute (BRRI). Those data were sourced from presented and/or published in BRRI annual review research workshops.

\section{RESULTS AND DISCUSSION}

\section{Status of rice diseases in Bangladesh}

The disease that causes economic loss in rice yield is defined here as a 'major' disease, while the one does not cause significant economic loss as 'minor'; the definition is more as subjective than quantitative. The identified rice diseases in Bangladesh have increased from 24 (1987 report) to 32 (2016 and 2018 reports) (Table 1; Appendix 1). Out of 32 diseases, 22 are caused by the fungus, six by nematodes, three by bacteria, and one each by virus and mycoplazma (Appendix 1). Currently, 11 diseases are recognized as major; this number was 10 in 1987 (Table 1) and 1993 (Shahjahan, 1993). Eight diseases (alphabetically, bacterial leaf blight, bakanae, blast, brown spot, sheath blight, sheath rot, ufra and tungro) have remained as major during 1987-2016 period. Two diseases (alphabetically, leaf scald and stem rot) that were classed as major in 1987 have currently been downgraded to a minor. On the other hand, three diseases (alphabetically, bacterial leaf streak, false smut, and seedling blight) are presently graded as major that were considered as minor in 1987. A recent study on the potential impact of climate change on crop diseases in Bangladesh showed the continued risk of major rice diseases but a likely monthly- shift in their incidence under given future climate scenarios (Salam et al., 2019).

\section{Yield loss scenarios due to rice diseases in Bangladesh}

Shahjahan (1993) states, "There is little quantitative data available on crop losses due to diseases on a regional or country scale in Bangladesh. Available reports are based on estimates because of the apparent lack of proper crop loss assessment methods and monitoring of pest and disease incidence in the country". The same author further mentions that the loss assessment due to diseases is difficult because of the following reasons: 
i) The yield or production in absence of the diseases is not known;

ii) Loss occurs only in a limited area, which must then be projected to estimate the loss over the whole crop;

iii) Loss may occur in one year or one season and needs to be averaged over several years; and,

iv) Loss may be on selected high infection, after artificial inoculation of selected crop timing.

Table 1. Rice diseases in Bangladesh during 1987 and 2016: the changes in number and status. The list (by common name) is in alphabetic order within boldbordered boxes.

\begin{tabular}{|l|l|l|}
\multicolumn{2}{|c|}{ Rice disease } & Status in \\
\hline Common name & Pathogen type & 1987 \\
Bacterial leaf blight & Bacteria \\
\hline Bakanae & Fungus \\
\hline Blast & Fungus \\
\hline Brown spot & Fungus \\
\hline Sheath blight & Fungus \\
\hline Sheath rot & Fungus \\
\hline Ufra & Nematode \\
\hline Tungro & Virus \\
\hline Bacterial leaf streak & Bacteria \\
\hline False smut & Fungus \\
\hline Seedling blight & Fungus \\
\hline Leaf scald & Fungus \\
\hline Stem rot & Fungus \\
\hline Aggregated sheath spot & Fungus \\
\hline Bacterial foot rot & Bacteria \\
\hline Crown sheath rot & Fungus \\
\hline Damping off & Fungus \\
\hline Grain red blotch & Fungus \\
\hline Grain spot & Fungus \\
\hline Kalo bij (Kernel spot) & Fungus \\
\hline Kernel smut & Fungus \\
\hline Leaf smut & Fungus \\
\hline Minute leaf spot & Fungus \\
\hline Narrow brown leaf spot & Fungus \\
\hline Root knot & Nematode \\
\hline Root lesion & Nematode \\
\hline Root rot & Nematode & \\
\hline Sheath blotch & Fungus \\
\hline Sheath spot & Fungus \\
\hline Stack burn & Fungus \\
\hline White tip & Nematode & \\
\hline Yellow dwarf & Mycoplasma & \\
\hline
\end{tabular}

Status class: Major (Gold dotted box); Minor (Green box); Not reported (White box)

Source: Miah and Shahjahan, 1987; BRRI, 2016; BRRI, 2018
Table 2 presents the national average yield loss scenarios due to rice diseases gathered from different sources. It is highly regarded by the expert, that national yield loss in rice ranges from 10 to $15 \%$, which includes diseases and insects (Miah and Shahjahan, 1987). It was Khan (1991) stated that the average yield loss due to rice diseases is $9.9 \%$ in Bangladesh. However, average losses due to diseases over the decade 198990 to 1998-99 was estimated as 3\% in Boro, $5.9 \%$ in Aus, and $6 \%$ in Aman with an average for three seasons is $4.9 \%$, contributed to an annual loss of 1.52 million ton per year (Islam and Catling, 2012). The authors also mentioned that those figures still to be regarded as an over estimation since farmer's perceptions were from which the data were derived strongly influenced by their worst memories of yield. A recent quick phone survey from 15 northern districts of Bangladesh with high officials of the Department of Agricultural Extension (DAE) revealed a different scenario, which accounted for less than $1 \%$ of yield loss in farmer's fields. However, this is a general annualized figure. The yield loss could go up in individual years when disease epidemics would be high. Kabir et al. (2020) has found similar results.

Table 2. National yield loss scenarios from rice diseases in Bangladesh.

\begin{tabular}{lllll}
\hline $\begin{array}{l}\text { Loss } \\
(\%)\end{array}$ & $\begin{array}{l}\text { Mode of } \\
\text { estimation }\end{array}$ & $\begin{array}{l}\text { Year of } \\
\text { reporting }\end{array}$ & Reference & Comments \\
\hline $10-15$ & $\begin{array}{l}\text { Highly } \\
\text { regarded } \\
\text { expert } \\
\text { opinion }\end{array}$ & 1987 & $\begin{array}{l}\text { Miah and } \\
\text { Shahjahan, insects } \\
1987\end{array}$ & \\
9.9 & $\begin{array}{l}\text { Survey } \\
\text { estimation }\end{array}$ & 1991 & Khan, 1991 - \\
4.9 & $\begin{array}{l}\text { Survey } \\
\text { estimation }\end{array}$ & 1999 & $\begin{array}{l}\text { Islam and } \\
\text { Catling, } \\
\text { 2012 }\end{array}$ \\
& & & Authors & - \\
\hline 1.0 & $\begin{array}{l}\text { Phone } \\
\text { survey }\end{array}$ & 2019 & & \\
\hline
\end{tabular}




\section{Yield loss under varying epidemics}

Blast, bacterial leaf blight, sheath blight, and more recently false smut are the heavy epidemic rice diseases in Bangladesh. Yield loss in severe infection conditions has been estimated as $65.4 \%$ and $56.9 \%$ for blast disease in the irrigated and rainfed ecosystem (Hossain et al., 2017) respectively in the farmers' field (Table 3).

Table 3. Yield loss estimation from blast in the farmers' fields under various epidemics in Bangladesh.

\begin{tabular}{llll}
\hline $\begin{array}{l}\text { Year of } \\
\text { reporting }\end{array}$ & $\begin{array}{l}\text { Loss } \\
(\%)\end{array}$ & Reference & Data environment \\
\hline 2017 & 65.4 & $\begin{array}{l}\text { Hossain } \\
\text { et al., } \\
2017\end{array}$ & $\begin{array}{l}\text { Variety specific (Jhalak } \\
\text { hybrid variety), highest } \\
\text { yield reduction in } \\
\text { irrigated ecosystem }\end{array}$ \\
2017 & 56.9 & $\begin{array}{l}\text { Hossain } \\
\text { et al., } \\
2017\end{array}$ & $\begin{array}{l}\text { Variety specific (BRRI } \\
\text { dhan34), highest yield } \\
\text { reduction in rainfed } \\
\text { ecosystem }\end{array}$ \\
2017 & 34.7 & $\begin{array}{l}\text { Hossain } \\
\text { et al., } \\
2017\end{array}$ & $\begin{array}{l}\text { Location-specific, } \\
\text { Among 30 agroecological } \\
\text { zones (AEZs), highest } \\
\text { yield loss in AEZ 9 }\end{array}$ \\
\hline
\end{tabular}

The yield loss from sheath rot disease was estimated as $75 \%$ under the highest disease severity (DS) scale of 9 (equivalent to $>80 \%$ of the panicles still enclosed by leaf sheath) (Ms Tuhina-Khatun, unpublished data, Plant Pathology Division, BRRI) (Fig. 1). While in the low disease severity scale (DS 1, equivalent to $\leq 20 \%$ of the panicles still enclosed by leaf sheath), the yield loss was recorded as $20 \%$. In a broad scenario, Shahjahan et al. (1994) recorded a yield loss of $31 \%$ when the crop was attacked at a critical stage due to sheath rot disease. For false smut disease, yield loss up to $87 \%$ was estimated when 67 smut balls were present in a panicle considered to be a severe outbreak situation (Fig. 2) (Nessa et al., 2015). For another important major disease, sheath blight caused $35 \%$ yield loss when the disease lesion reached about $80 \%$ of the plant height (B

Khatun et al.
Nessa, unpublished data, Plant Pathology Division, BRRI) (Fig. 3).

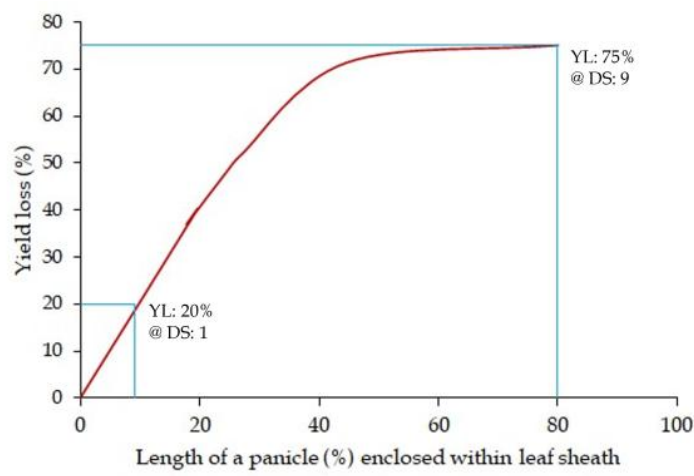

Fig. 1. Estimated yield loss from sheath rot in a severely naturally infected rice field ( $100 \%$ incidence). DS: disease severity scale, YL: yield loss. DS 1: 0-20\% of panicles still enclosed by leaf sheath; DS 3: 21$40 \%$ of panicles still enclosed by leaf sheath; DS 5: $41-60 \%$ of panicles still enclosed by leaf sheath; DS 7: $61-80 \%$ of panicles still enclosed by leaf sheath; DS 9: $>80 \%$ of panicles still enclosed by leaf sheath. DS 1 represents a low disease severity scale, while DS 9 the highest disease severity scale. Unpublished data (M Tuhina-Khatun, Plant Pathology Division, BRRI).

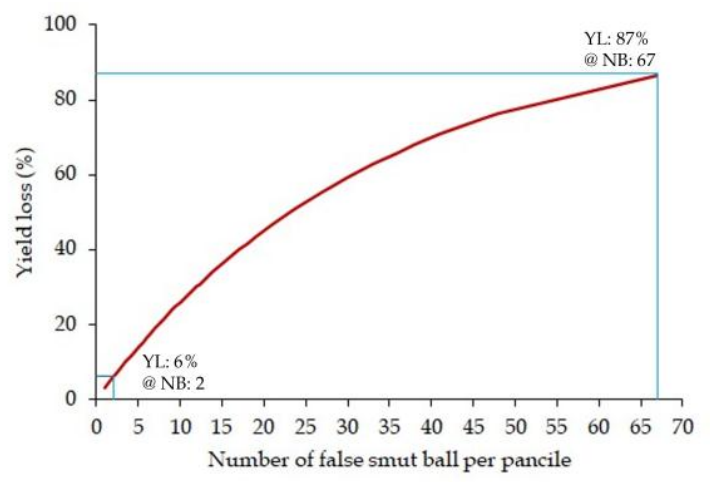

Fig. 2. Estimated yield loss from false smut infected rice fields. NB denotes the number of false smut infected balls per panicle, and YL for yield loss. Data from Nessa et al. (2015) 


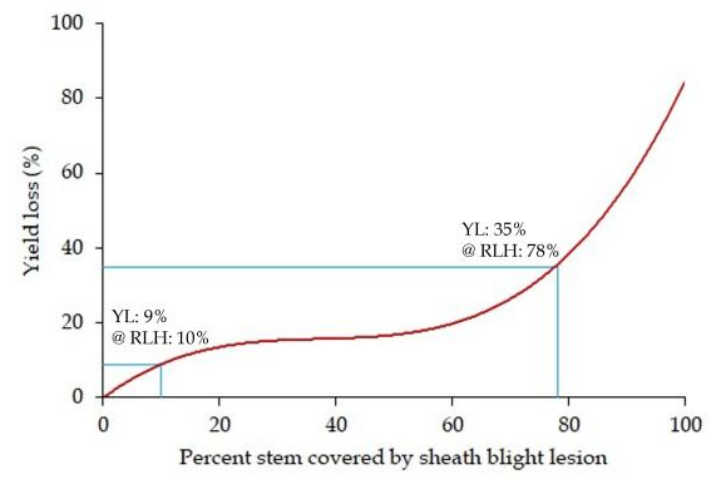

Fig. 3. Estimated yield loss from sheath blight infected rice fields. RLH denoted for relative lesion height of sheath blight disease as 0 to 100 percent. RLH 10 and RLH 78 indicate the disease symptom reached up to 10 and $78 \%$ of total plant height, respectively. YL is yield loss. Unpublished data (B Nessa, Plant Pathology Division, BRRI).

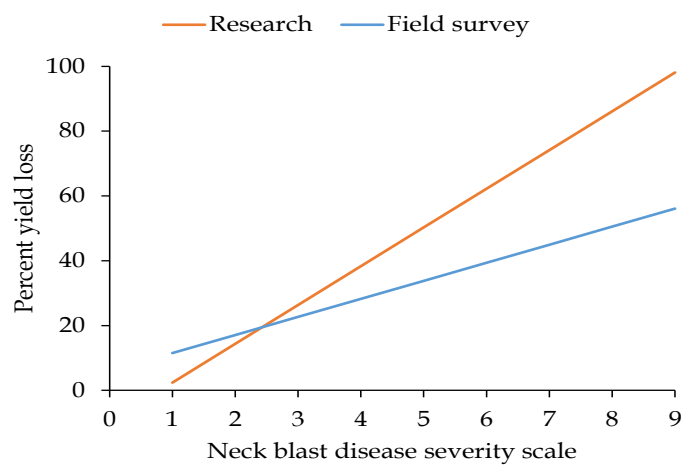

Fig. 4. Yield loss in rice due to blast disease under the whole range of disease severity scale based on research data and field survey data. The number on the $x$-axis, 1 , indicates the lowest disease severity scale and 9 the highest disease severity scale. Odd year means the year when severe disease outbreak occurs. The research data represent the odd years when the yield loss in infected fields reached above $40 \%$.

Yield loss under epidemic condition in odd year

It has been observed by rice scientists that a disease outbreak or epidemic generally occurred at several years intervals when favourable weather conditions prevail for a specific pathogen, and appropriate crop stages are available in the field for that organism. Currently, blast is such an epidemic disease that causes significant yield loss in farmers' fields. From research findings in farmer field under the devastating situation, blast caused the highest amount of yield loss up to $98 \%$ at disease severity scale of 9 , when all the rice panicles in the field were severely affected by blast fungus (B Nessa, Plant Pathology Division, BRRI) (Fig. 4). From field survey, Hossain et al. (2017) recorded a yield loss of up to $56.1 \%$ due to this disease in farmers' fields from 10 agroecological zones of Bangladesh (Fig. 4).

\section{Disease management under severe epidemics occur in odd year}

The following are the potential ways to manage rice disease successfully under severe epidemics in the odd year.

\section{A. Varietal interventions}

The use of resistant or tolerant variety is the most economical and environmentally friendly method for the management of rice diseases especially for devastating diseases such as blast (Khan et al., 2001; Haq et al., 2002). However, the resistance is subject to break down due to the appearance of new or more virulent races of the pathogen (Ghazanfar et al., 2009). Therefore, it is necessary to continually speed up the breeding program to develop resistant rice varieties for blast and other serious diseases. Plant Pathology Division of BRRI has developed some promising lines in the background of BRRI dhan28 and BRRI dhan29 to combat blast epidemics, which are in pipeline to release as varieties, which could be used in the future for cultivation in blast endemic areas.

\section{B. Preventive measures}

To control rice diseases in the farmers' field, it is economically feasible and sound to apply preventive measures rather than a curative ones. Following are some techniques which could be applied extensively to minimize disease outbreak in farmers field: 
i. Use of disease free healthy seed

ii. Balanced application of phosphorus and potassium fertilizer

iii. Avoidance of excessive use of nitrogenous fertilizer

iv. Application of potash fertilizer in two splits. One split at the time of land preparation and the other at the time of last top-dress with urea fertilizer

v. Avoidance of seedbed preparation if the seedbed are disease infected in the previous year

vi. Destruction of stubbles and debris

vii. Destruction of alternate host

viii. Practice of wider spacing between two hills to avoid favourable condition for pathogen growth and development

ix. Avoid cultivation of susceptible variety

$x$. Following of crop rotation

xi. Seed treatment with chemicals

\section{Strong forecasting system}

Since disease epidemics or disease outbreaks mostly depend on weather parameters, therefore, it is urgent to develop a strong and precise weather-based disease risk forecasting system with at least one-week lead-time based on real-time weather data. The quick management option such as fungicidal treatment should also be broadcast along with weather forecasting. Digital platforms such as broadcast through TV channels, SMS to rice farmers, pronouncement through all mobile operators during phone call, and digital display of management packages at block level could be efficient and effective ways to address the disease outbreak under epidemics situation. For example: if the weather is conducive for blast disease at the booting stage, alert to be delivered to farmers through all channels recommending application of Tricyclazole/Strobin group of fungicides to rice fields in the afternoon on the susceptible varieties such as BRRI dhan 28 and BRRI dhan29.

\section{Effective training and advice to farmers and baseline extension agents for proper identification of rice diseases}

"The farmers of rural Bangladesh, whether large or small, still depend largely on homegrown, indigenous methods-handed down from father to son to fight their unknown enemies that deplete their harvests each season" (Shahjahan, 1993). Since rice has been cultivated in Bangladesh for more than centuries and hopefully it will continue to cultivate for centuries-long then there is no alternative to provide every true farmer and Sub-Assistant Agricultural Officers (SAAOs) learning, training, knowledge, and every source of information to properly identify every type of rice disease and also manage and/or control those effectively. Initially, it will be costly and time-intense, however, in the long run, it will return enormous benefit to the country. In this context, BRRI regional stations can take a master plan to train all rice growers in their commanding areas on a longterm basis. Recently developed 'BRRI Rice Doctor' will be helpful for educated farmers to identify and manage rice diseases successfully.

\section{E. Regularly monitoring of rice field}

Monitoring and early detection would be very helpful for prevention of the rice diseases (Kim et al., 2017). Monitoring of rice disease progress aims to forecast and decide the time for control action as well as assess the effect of management. Therefore, it is strongly recommended and advised to the farmers and SAAOs to regularly monitor their own fields and surveillance area. For example, early detection of rice leaf blast can be managed by irrigation in the field. Likely, the appearance of Kresek (bacterial foot rot) and bacterial leaf blight (BLB) can effectively control through drainage/removing of water for few days or following alternate wetting and drying technology. Brown spot disease, therefore, could successfully be managed by balanced urea fertilization. These are the simple 
management practices farmers can easily adapt to their rice field by early detection of the symptoms through regular supervision and control the diseases effectively. It is now realized in both developed and developing countries that there should be a permanent program at all national levels to monitor changes in diseases outbreaks by plant pathologists, resulting from a breakdown of the inherent resistance of certain varieties, the development of pesticide resistance in the pathogens, or a shift in disease incidence due to changes in cultural practices (Shahjahan, 1993).

\section{F. Epidemiological study}

Epidemiology is defined as the study of factors that affect the spread of disease in time and space (Madden et al., 2007). These factors include temperature, moisture, humidity, and precipitation, etc. that influence the pathogen either positively or negatively depending on the requirement of a pathogen (Arya, 2018) to develop a particular disease. Epidemiological studies are important for the management of rice diseases as the obtained data can be processed and transformed into technologies for the management of pathogens (Arya, 2018). Such studies can be used as strategies for managing plant disease epidemics, and we can organize our plant disease control tactics under: (a) reduction of the initial inoculum/pathogen, (b) reduction of the infection rate, and (c) reduction of the duration of the epidemic, following one or more of the strategies are stated below (adopted from Arya, 2018):

i. Avoidance: Reduce the level of disease by selecting a season or a site where the amount of pathogen/inoculum is low or where the environment is unfavorable for infection, eg., right time of planting of BRRI dhan49 escapes false smut.

ii. Exclusion: Reduce the amount of initial inoculum introduced from outside sources. The infection of BLB and bacterial leaf streak (BLS) is more concentrated in hybrid. Therefore, restriction/regulation in hybrid import will reduce BLB and BLS incidence in the rice field. BRRI has already developed six hybrids that are less susceptible to BLB and BLS infection. Farmers should be encouraged to cultivate BRRI released hybrids rather than foreign hybrids, later one is more susceptible to diseases in our environment.

iii. Eradication: Reduce the production of initial inoculum by destroying or inactivating the sources of an initial pathogen such as rouging, burning of straw, destruction of alternate host, etc. These are applicable for sheath blight, sheath rot, and stem rot diseases of rice.

iv. Protection: Reduce the level of initial infection by means of a toxicant or other barrier to infection such as spraying fungicides.

v. Resistance: Use cultivars/varieties that are resistant to infection, particularly the initial infection.

The epidemiological knowledge has to reach the resource-poor farmers through farmers' groups such as farmers' field school (FFS). The FFS uses discovery-based learning methods to improve the farmers' agro-ecological knowledge, and their capacity to make decisions (Van De Fliert et al., 2002). The group of farmers gathers in a weekly meeting and shares their knowledge regarding the production constraints during the rice-growing season and by team discussions, they can make decisions for practical actions in the field.

G. Location-specific, variety specific and disease-specific smart disease management packages

There are some areas that tend to more vulnerable to a specific disease. For example, Habiganj district is prone to tungro disease, the Barishal region is favourable for ufra disease, and the incidence of the brown spot is higher in Satkhira district. To manage the 
specific disease in this specific location, we should suggest location-specific technology. For instance, to avoid tungro in Habiganj during Aus season, we can suggest farmers cultivate a variety like BR8 because it has the highest potential to recover from tungro disease after being affected by tungro virus (Khatun et al., 2017). Similarly, BRRI dhan37 has the highest potential to give better yield against tungro during T. Aman season (Khatun et al., 2017). Likely, if we advocate farmers to cultivate BRRI dhan49, then we should suggest farmers to planting BRRI dhan49 with the 'recommended-sowingwindow' that means within 15 June to 14 July; if the variety is sown on or before 1 July, it would most likely escape the major risk of the false smut disease and the infection rate will be less than 1\% (Nessa, 2017). If the farmers are planting BRRI dhan28 and BRRI dhan29, and the favourable weather (drizzling, prolong dew in the morning, night time cool but day time hot and cloudy weather) for blast disease development prevail during booting stage, then to strongly suggest applying fungicides from the groups Tricyclazole or Strobin to save their crop from significant or severe loss.

\section{H. Instant delivery of disease risks together with remedies}

We are making progress on circulating disease management packages to the farmers through diverse ways, namely leaflet, booklet, website, mobile apps like BRRI mobile apps (RKB), krishoker Janala, etc. Through these techniques, we have already reached a section of farmers but not all. The truth is most of our farmers are not compatible with website browsers or mobile apps. We must be more digitalized to deliver our latest management technology to all rice farmers by rapid but easier techniques. Such as by sending SMS through all mobile operators to all customers and/or farmers in Bangla, so that the less educated farmers can follow it. For example, when the rice crop is in the field, and a heavy rain-storm is predicted, we can send an SMS to all farmers with the message - "Don't apply urea fertilizer in your rice field, it will increase BLB incidence".

Table 6. Sustainability, external inputs needed, and labor requirements of selected plant disease management practices of traditional farmers (most, but not all, of these practices are sustainable in the long term).

\begin{tabular}{llll}
\hline Practice & Sustainable? & External inputs & Labor \\
\hline Adjusting crop density & Yes & Low & Low \\
Adjusting planting depth & Yes & Low & Low \\
Adjusting planting time & Yes & Low & Low \\
Altering of plant and crop architecture & Yes & Low & High \\
Biological control (soilborne pathogen) & Yes & High & High \\
Burning & Yes & Low & High \\
Fallowing & Yes & Low & Low \\
Flooding & Yes & Low & High \\
Manipulating & Yes & Low & High \\
Mulching & Yes & High & Low \\
Multistory cropping & Yes & Low & High \\
Multiple cropping & Yes & Low & Low \\
Planting diverse crops & Yes & Low & High \\
Planting in raised beds & Yes & High & Low \\
Rotation & Yes & Low & Low \\
Site selection & Yes & Low & High \\
Tillage & No & Low & High \\
Using organic amendments & Yes & High & High \\
Weed control & No & Low & \\
\hline
\end{tabular}

aUnder high population pressure, the slash, and burn system is neither stable nor sustainable. Source: Thurston, 1992. 


\section{Farmers indigenous and traditional technologies}

It is important to preserve and accumulate indigenous and traditional technologies which have been practicing by rural farmers for a long. The term traditional farming is usually associated with primitive agricultural systems or preindustrial peasant agriculture that has been practiced for many generations (Thurston, 1994) in the farmers' field.

Most practices for disease management used by indigenous farmers in developing countries are cultural practices, but little information is available in an easily accessible form. Table 6 presents many of the practices of the indigenous farmers (Thurston, 1994). Today there are serious concerns about "modern agriculture", which is extremely energy-intensive, the genetic base is narrow, and stress on increasingly high yields and efficiency leads to monoculture, and sometimes to serious erosion, pollution, and excessive pesticide residues (Thurston, 1994). A historical perspective on the practices and genetic materials used by traditional farmers through the centuries may help us to develop truly sustainable agriculture. To reduce reliance on pesticides, which our poor/marginal farmers are unable to afford, and to eliminate the risk of environmental pollution, attention should be given to nonchemical methods (genetic, mechanical, cultural, and biological) of control such as burning stubble/crop residues, water management, ash application, and spraying botanics (Shahjahan, 1993). These indigenous practices should be restored and practiced to provide safe food that is also one of our sustainable development goals.

\section{J. Strengthening network between farmers and scientists}

It is of utmost necessary to make bridge the gap between farmers and scientists. Here, we have proposed a simple model/diagram (the idea adopted from Rhoades and Booth, 1982) to identify the disease problem by plant pathologists from the farmers' field, to do basic research on diseases, and to do applied research on management practices (Fig. 6). Sometimes it may require interdisciplinary collaboration with an entomologist, soil scientists, and agronomist to identify genuine problems that arise from a farmer's field. After extensive researches, potential or possible solutions should go through evaluation and adaptation under researcher supervision and farmers' perception. Finally, farmers' accepted technology will go for dissemination. This is a continuous process between farmers, scientists, and extension personnel to generate sustainable technology arise directly from farmer's field on rice diseases. To achieve maximum benefit there should be a strong linkage between research, extension, and the technology users, i.e. the farmers (Shahjahan, 1994).

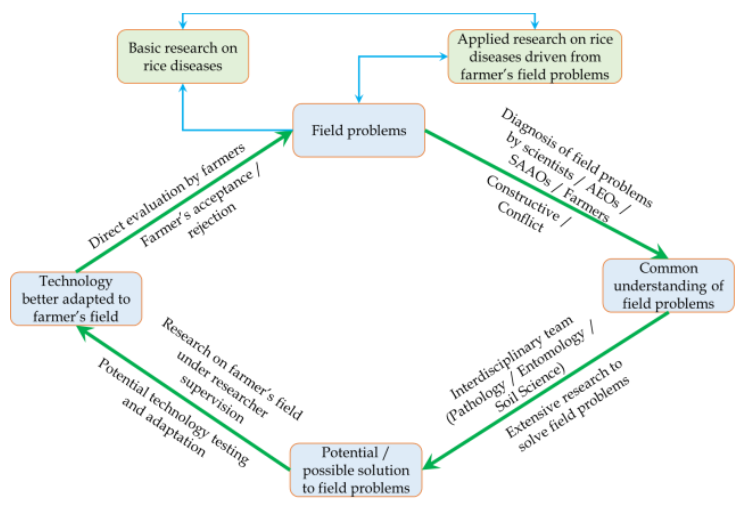

Fig. 6 Network between farmers and scientists to generate technology (Idea adapted from Rhoades and Booth, 1982).

K. Demonstrations to disseminate integrated disease management strategies to farmers field

To disseminate the latest technology, it is crucial to demonstrate it directly in the farmers' field. Whatever technologies are available or generated should reach the farmers through communication materials such as bulletins or folders; those to be 
written in local language and be distributed to extension agents (Shahjahan, 1993). Recent demonstrations of integrated disease management packages in farmer's field have recorded a reduction of blast disease incidence in BRRI recommendation practices over the farmers' practices by 43.57 to $70.88 \%$ (Tuhina-Khatun et al., 2018). The yield increase with BRRI management practices was 0.82 to $1.18 \mathrm{t} \mathrm{ha}^{-1}$ (Table 7: partial data are shown). For sheath blight disease management in Aus rice, it was observed that the disease incidence in farmers' fields in Gopalganj was reduced by $68.89 \%$ and $73.95 \%$ with trichocompost and fungicides application, respectively (Jahan, 2017). There were also advantages of yield by 0.49 to $0.69 \mathrm{t}$ ha $^{-1}$ in BRRI managed plots (Jahan, 2017). The above findings in relation to the two major disease management delivers a clear message that effective control of devastating diseases is possible in farmers' fields, which will increase the yield.

Here, we have given simple mathematics, how could we minimize our yield loss, for example, in 2020 through our existing management techniques.
Lets consider, in 2020, we have a target of clean rice production of 37.0 million tons. If we expect the maximum $1 \%$ loss due to diseases, then it will be 0.37 million tons of clean rice production loss in the whole country. We have yield advantage in our disease management plots are $0.49,0.69,0.82$, $1.18 \mathrm{t} \mathrm{ha}^{-1}$ in different locations in farmers fields. If we consider conservative figure, we will be able to increase yield at least $0.49 \mathrm{tha}^{-1}$ through our existing management packages. And, if we assume the rice land for T. Aman 2020 as 5.0 million hectares, then the production will be increased by at least 2.45 million tons. Practically, it is not possible to receive a yield advantage from $100 \%$ rice field. If we get yield advantage from $50 \%$ or even at least $25 \%$ field, then, we have a minimum of 1.23 or 0.61 million ton of rough rice production advantage, which will be, hopefully, enough to meet the loss of 0.37 million ton of clean rice production in 2020 (assuming we will have to disseminate our rice disease management technologies through our all possible channels to the farmers' field).

Table 7. Demonstrations on rice blast disease management executed in Gazipur district of Bangladesh in Boro season, 2017-18.

\begin{tabular}{|c|c|c|c|c|c|c|c|}
\hline \multirow[t]{2}{*}{ Variety } & \multicolumn{2}{|c|}{ Disease incidence (\%) } & \multirow{2}{*}{$\begin{array}{l}\text { Disease } \\
\text { reduction (\%) }\end{array}$} & \multicolumn{2}{|c|}{ Yield (t ha-1) } & \multirow{2}{*}{$\begin{array}{l}\text { Yield } \\
\text { increase } \\
\left(\mathrm{t} \mathrm{ha}^{-1}\right)\end{array}$} & \multirow{2}{*}{$\begin{array}{l}\text { Yield } \\
\text { increase (\%) }\end{array}$} \\
\hline & $\begin{array}{l}\text { BRRI } \\
\text { practice }\end{array}$ & $\begin{array}{l}\text { Farmer } \\
\text { practice }\end{array}$ & & $\begin{array}{l}\text { BRRI } \\
\text { practice }\end{array}$ & $\begin{array}{l}\text { Farmer } \\
\text { practice }\end{array}$ & & \\
\hline $\begin{array}{l}\text { BRRI } \\
\text { dhan28 (L-1) }\end{array}$ & 7.75 & 19.61 & 60.48 & 6.22 & 5.90 & 0.32 & 5.42 \\
\hline $\begin{array}{l}\text { BRRI } \\
\text { dhan29 } \\
\text { (L-2) }\end{array}$ & 0.00 & 30.19 & 100 & 8.75 & 7.46 & 1.29 & 17.29 \\
\hline $\begin{array}{l}\text { BRRI } \\
\text { dhan28 } \\
\text { (L-3) }\end{array}$ & 12.00 & 22.22 & 45.99 & 4.99 & 4.43 & 0.66 & 12.64 \\
\hline $\begin{array}{l}\text { BRRI } \\
\text { dhan28 } \\
\text { (L-4) }\end{array}$ & 3.85 & 16.77 & 77.04 & 5.92 & 4.93 & 0.99 & 20.08 \\
\hline Average & 5.90 & 22.20 & 70.88 & 6.47 & 5.68 & 0.82 & 13.75 \\
\hline
\end{tabular}

Note: L-1: Kapasia-Trial 1; L-2: Kapasia-Trial 2; L-3: Shreepur-Trial 1; L-4: Shreepur-Trial 2 (Source: Tuhina-Khatun et al., 2018) 
Action plan for three decades on reducing yield loss from rice diseases

"Location, Variety, and Disease Specific Smart Management (LVDSSM)" will be the banner of the action plan for plant pathology of BRRI in the next three decades 2021-30, 2031-40, and 2041-50. Table 8 shows the salient features of the LVDSSM.

Table 8. The salient features of the action plan on 'Location, Variety and Disease Specific Smart Management' (LVDSSM) for plant pathology of BRRI in the next three decades - 2021-30, 2031-40 and 2041-50.

\begin{tabular}{|c|c|c|c|}
\hline Programme & Phase & Stage & Action \\
\hline \multirow[t]{6}{*}{$\begin{array}{l}\text { Research \& } \\
\text { Development }\end{array}$} & Primary & YL-EST & $\begin{array}{l}\text { - Identification (symptom \& the disease) } \\
\text { o Isolation (for genetic ID \& propagation behavior) } \\
\text { - Inoculation (mass inoculation technique) } \\
\text { - Yield loss estimation (by disease severity scale) }\end{array}$ \\
\hline & Intermediate & Mtg-FWK & $\begin{array}{l}\text { - Management framework (considering all possible options, based on } \\
\text { current knowledge) }\end{array}$ \\
\hline & & EPI & $\begin{array}{l}\text { Epidemiology (based on local conditions, not just on information } \\
\text { from literature. Finding the exact driver(s) of the disease epidemics }\end{array}$ \\
\hline & Maturation & & $\begin{array}{l}\text { Calibration and Validation (testing every component of the } \\
\text { management framework by location \& variety; applying all tools) }\end{array}$ \\
\hline & & SmMtg & $\begin{array}{l}\text { - Smart management package developed to be acceptable to farm } \\
\text { adoption }\end{array}$ \\
\hline & Follow up & $\mathrm{CO}$ & $\begin{array}{l}\text { Continuous observations to keep on notice if changes happening on } \\
\text { smart management package, e.g., variety tolerance; reaction to new } \\
\text { varieties }\end{array}$ \\
\hline \multirow[t]{3}{*}{ Dissemination } & Phase-1 & Train & - Training (DAE officers and lead farmers) \\
\hline & Phase-2 & Demo & Demonstration (in the location of disease risk) \\
\hline & Phase-3 & EW & - Early warning system-based disease alert communicated to farmers \\
\hline
\end{tabular}

The plan consists of two broad programmes research and development ( $R$ and $\mathrm{D})$, and dissemination. The $R$ and $D$ will progress through four phases - (i) primary, (ii) intermediate, (iii) maturation, and (iv) followup. The primary phase will be completed in two stages - (i) III (identification of symptoms of the diseases and the pathogens; isolation of the pathogens for genetic identification and propagation behaviour; inoculation for disease development with the associated pathogen, and (ii) YL-EST, which is the yield loss estimation for each major disease by disease severity scale. The intermediate phase will pass through two stages - Mtg-FWK (which is the development of management framework considering all possible options, based on past and current knowledge), and EPI (i.e., epidemiology based on local conditions, not just on information from literature in order to find the exact driver(s) of the disease epidemics). The maturation phase will be completed in two stages - Cali-Valid (which is calibration and validation to undertake to test, by applying all tools, of every component of the management framework, and SmMtg (which is the development of a smart management package to be acceptable to farm adoption). The singlestage follow-up (CO) phase will be the continuous observations to keep on notice if changes happen on the smart management package, such as variety tolerance, reaction to new varieties, etc.

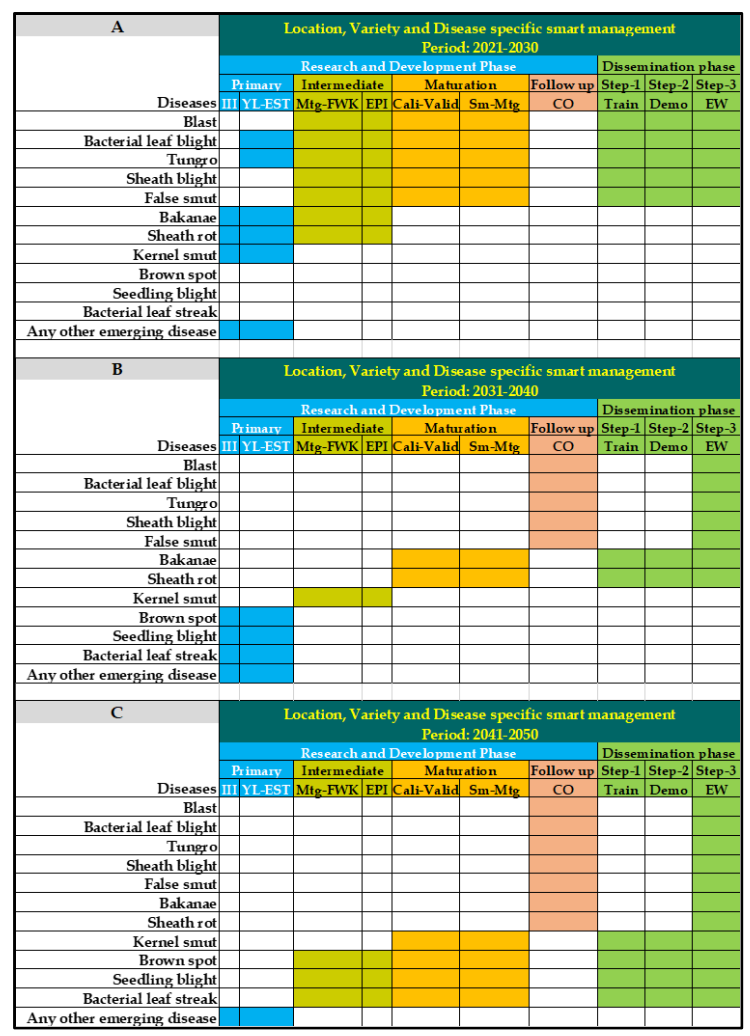

Fig. 7. The action plan on 'Location, Variety, and Disease Specific Smart Management' for plant pathology of the Bangladesh Rice Research Institute (BRRI) in the next three decades: 2021-30 (A), 2031-40 (B), and 2041-50 (C). III denotes for identification of symptom(s) and diseases, isolation for biology study and genetic identification, and inoculation for reproducing the disease; YL-EST for the yield loss estimation for major disease by disease severity scale; Mtg-FWK for development of management framework considering all possible options, based on past and current knowledge; EPI for 
epidemiology based on local conditions, not just on information from literature in order to find the exact driver(s) of the disease epidemics; Cali-Valid for calibration and validation to undertake testing, by applying all tools, of every component of the management framework; SmMtg for development of smart management package to be acceptable to farm adoption; and CO for continuous observations to keep on notice if changes happen on smart management package, such as, variety tolerance, reaction to new varieties, etc.

The dissemination programme will be carried out in single-staged three phases, which includes training of officers of the Department of Agricultural Extension (DAE) and lead farmers (Trained), demonstration in the locations of specific disease risk (Demo), an early warning system-based disease alert communicated to farmers (EW).

Figure 7 shows the time dimension of the action plan for 10 major diseases in the next three decades, 2021-30, 2031-40, and 2041-50. If any diseases become a concern, they will be included in the plan. The plan has assigned varieties according to the importance and present $R \& D$ status.

\section{CONCLUSION}

The key drivers to meet food demand and sustain rice production in future are the farmers. Hence, emphasis has to be given to the farmers, and how they could reach to the existing technologies on rice disease management. However, acceptance of the technologies by the farmers depends on the authenticity of the technologies developed by the researchers. The proposed action plan accommodates both the requirements.

\section{ACKNOWLEDGEMENTS}

The authors wish to thank anonymous reviewers for their suggestions, which significantly improved this article.

\section{AUTHORS' CONTRIBUTION}

MTK, BN, MUS and MSK generated idea; BN and MUS coordinated the research; MTK and
BN developed methodology; MTK, BN and MUS provided scientific insights; MTK and BN gathered data, carried out analysis and synthesis; MTK and MUS did the writings for all versions of the manuscript; MUS and MSK performed critical review and editing; All authors read and approved the final manuscript.

\section{DECLARATION OF INTERESTS}

The authors declare that they have no known competing financial interests or personal relationships that could have appeared to influence the work reported in this paper.

\section{REFERENCES}

Arya, A. 2018. Role of epidemiology in plant disease management. International Journal of Chemical Studies, 6(1): 1651-1655.

BRRI (Bangladesh Rice Research Institute). 2016. Dhan chaser somossa (Problems in rice cultivation). Bangladesh Rice Research Institute, $5^{\text {th }}$ edition. Bangladesh Rice Research Institute (BRRI), Gazipur1701, Bangladesh, 1-78.

BRRI (Bangladesh Rice Research Institute). 2018. Adhunik Dhaner Chash (Modern rice cultivation), 21 ${ }^{\text {st }}$ edition. Bangladesh Rice Research Institute (BRRI), Gazipur1701, Bangladesh, 91.

Ghazanfar, M U, A Habib A and S T Sahi. 2009. Screening of rice germplasm against Pyricularia oryzae the cause of rice blast disease. Pakistan Journal of Phytopathology, 21 (1): 41-44.

Haq, I M, M Fadnan, F F Jamil and A Rehman. 2002. Screening of rice germplasm against Pyricularia oryzae and evaluation of various fungitoxicants for control of disease. Pakistan Journal of Phytopathology, 14(1): 32-35.

Hossain, M, M A Ali and M D Hossain. 2017. Occurrence of Blast Disease in Rice in Bangladesh. American Joirnal of Agricultural Sciences, 4 (4): 74-80.

Islam, Z and D Catling. 2012. Rice pest of Bangladesh: Their ecology and management. The university press limited, Dhaka, 1-422.

Jahan, Q S A. 2017. Management of Sheath blight disease utilizing Trichoderma harzianum (PGB project). BRRI annual research review workshop report 2016-17, Plant Pathology Division, held from24 February 2018 to 1 March 2018.

Kabir, MS, M U Salam, A Chowdhury, N M F Rahman, K M Iftekharuddaula, M S Rahman, M H Rashid, S S Dipti, A Islam, M A Latif, A K M S Islam, M M 
Hossain, B Nessa, T H Ansari, M A Ali and J K Biswas. 2015. Rice Vision for Bangladesh: 2050 and Beyond. Bangladesh Rice Journal, 19 (2):1-18.

Kabir, MS, M U Salam, A K M S Islam, M A R Sarkar, M A A Mamun, M C Rahman, B Nessa, M J Kabir, H B Shozib, M B Hossain, A Chowdhury, M Nasim, K M Iftekharuddaula, M S Hossain, M K A Bhuiyan, B Karmakar, M S Rahman, M M Haque, M T Khatun, M P Ali, S M H A Rabbi, P L Biswas, E S M H Rashid and N M F Rahman. 2020: Doubling rice productivity in Bangladesh: A way to achieving SDG 2 and moving forward. Bangladesh Rice Journal, 24 (2): $1-47$.

Khatun, M T, M A Latif, M M Rahman, M Hossain, T H Ansari, B Nessa, M A I Khan, M A Ali and M M Hanafi. 2017. Recovering ability of upland and rainfed lowland rice varieties against rice tungro disease. Bangladesh Rice Journal, 21 (1):91-100.

Khan, A R. 1991. Crop loss and waste assessment. A consultancy report. USAID/BARC/CCCI. 1-122.

Khan, J A, F F Jamil, A A Cheema, M A Gill. 2001. Screening of rice germplasm against blast disease caused by Pyricularia oryza. In: Proceedings of National Conference of Plant Pathology, held at NARC, Islamabad, Pakistan.

Kim, Y, K Jae-Hwan Roh and H Y Kim. 2017. Early forecasting of rice blast disease using long shortterm memory recurrent neural network. Sustainability, 10: 34.

Madden, L, G Hughes and F V D Bosch. 2007. Study of plant disease epidemics. American Phytopathology Society, 421.

Miah, S A and A K M Shahjahan. 1987. Mathe dhaner rog nirnoy o tar protikar (Field identification of rice diseases and their control). BRRI publication, Gazipur, Bangladesh.

Nessa, B, M U Salam, A H M M Haque, J K Biswas, W J MacLeod, M A Ali, K P Halder and J Galloway. 2015. FLYER: A simple yet robust model for estimating yield loss from rice false smut disease (Ustilaginoidea virens). American Journal of Agricultural and Biological Sciences, 2015: 41-54. DOI: 10.3844/ajabssp.

Nessa, B. 2017. Rice False smut disease in Bangladesh: epidemiology, yield loss and management. PhD thesis. Department of Plant Pathology and Seed Science, Sylhet Agricultural University, Sylhet, Bangladesh.

Rice diseases workshop. 2014. Improving epidemiology and disease diagnosis for sustainable management. Workshop held on 24-26 November 2014 in Montpellier, France.
Rhoades, R and Booth R. 1982. Farmer-back-to-farmer. Agricultural Administration, 11: 127-137.

Salam, M U, J K Timothy, M Carlo, B Nessa, M TuhinaKhatun, M P Ali, S Ishtiaque, M A Mannan, S M Q Hassan, M Aziz and M S Uddin. 2019. Climate change and Bangladesh agriculture: Adaptation and mitigation strategies. In: Potential impact of climate change on crop insect pests and diseases in Bangladesh: Future scenarios and strategies for climate services, Krishi Gobeshona Foundation. Bangladesh Agricultural Research Council. Farmgate, Dhaka, 105-135.

Shahjahan, A K M. 1993. Practical approaches to crop pest and disease management in Bangladesh. Bangladesh Agricultural Research Council, Farmgate, Dhaka.

Shahjahan, A K M, S I Akanda, A H Mondal and N S Nahar. 1994. Relation of sheath rot (Sarocladium oryzae) severity to yield of rice. Bangladesh Journalk of Botany, 23 (2): 211-215.

Shahjahan, A K M. 1994. Practical approaches to rice blast disease management in tropical monsoon ecosystems, with special reference to Bangladesh, Rice blast disease, $C A B$ International, Wallingford, UK, 1-488.

Shen, M and J Y Lin. 1994. The economic impact of rice blast disease in China, Rice blast disease, $C A B$ International, Wallingford, UK, 321-331.

Teng, P S. 1994. The epidemiology basis for blast management, Rice blast disease, $C A B$ International, Wallingford, UK, 409-433.

Thurston, H D. 1992. Sustainable practices for plant disease management in traditional farming systems, Westview, Boulder, Colorado, 279.

Thurston, H D. 1994. Assessing indigenous and traditional knowledge in farning systems, Rice blast disease, $C A B$ International, Wallingford, UK, 541-558.

Tuhina-Khatun, M, S Akter and B Nessa. 2018. Integrated management of blast disease for enhancing rice production in relation to climate change. Presented in BRRI annual research review workshop 2017-18, Plant Pathology Division, held from 2 February 2019 to 7 February 2019.

Van De Fliert, E, R Dilts and J Pontius. 2002. Farmer researcher teams, farmer field schools and community IPM: Different platforms for different research and learning objectives. In: Leeuwis, C and Pyburn, R (eds), Wheelbarrows Full of Frogs: Social Learning in Rural Resource Management. Royal Van Gorcum BV, Assen, The Netherlands. pp 120-33.

Zeigler, R S, S A Leong and P S Teng. 1994. Rice blast disease, $C A B$ International, Wallingford, UK. 


\section{Appendix 1. List of identified rice diseases in Bangladesh (the list is in alphabetic order within the disease-causing organisms).}

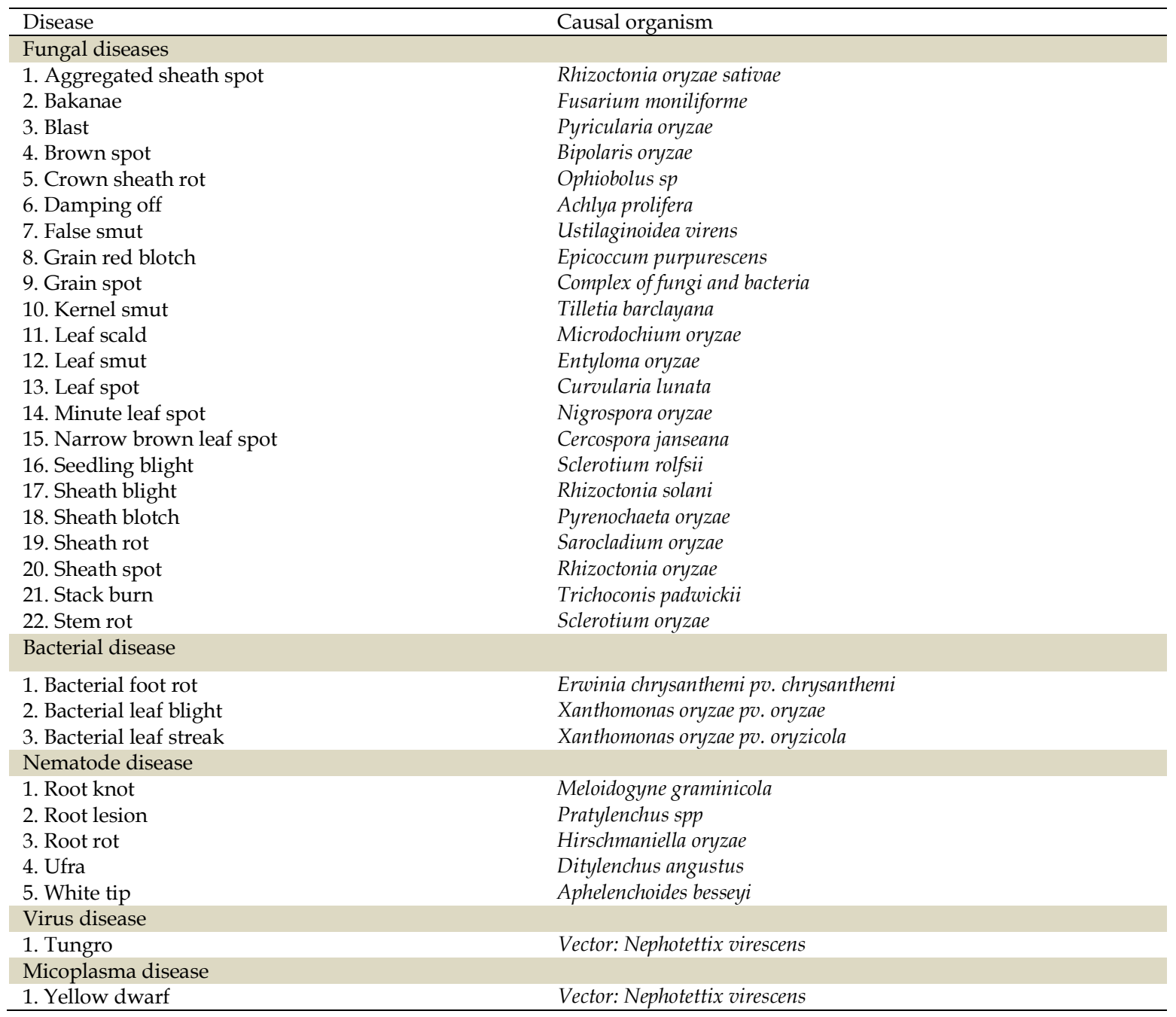

